\title{
Effects of Serotonin Antagonist, Cyproheptadine, and Serotonin Depletor, $p$-Chlorophenylalanine, on Feeding in Rats Kept at High and Temperate-Ambient Temperatures
}

\author{
Youhei Kurose*, Hideo Y ANO $^{1)}$ and Akira MiYAZAKI \\ Laboratory of Animal Resources and "Laboratory of Animal Nutrition, \\ Faculty of Agriculture, Kyoto University, Sakyo-ku, Kyoto-shi 606
}

(Received January 23, 1995)

\begin{abstract}
The present study was conducted to examine the participation of serotonin (5 HT) in the regulation of appetite in rats acclimated to hot $\left(33^{\circ} \mathrm{C}\right)$ and temperate $\left(26^{\circ} \mathrm{C}\right)$ environments. The central administration of noradrenaline exerted a stimulative effect on food intake at 26 and $33^{\circ} \mathrm{C}$. However, the increment of food intake after noradrenaline administration at $33^{\circ} \mathrm{C}$ was less than that at $26^{\circ} \mathrm{C}(0.4$ vs. $1.0 \mathrm{~g})$. Cyproheptadine, a $5 \mathrm{HT}$ antagonist, did not stimulate feeding in rats given noradrenaline at the two temperatures. Food intake was increased by cyproheptadine alone at $26^{\circ} \mathrm{C}$, but not at $33^{\circ} \mathrm{C}$. Thus, serotoninergic activity might not be correlated with the suppression in eating elicited by noradrenaline in the hot environment. In a daytime, there was not a significant difference in food intake between the two temperatures before $p$-chlorophenylalanine (PCPA), a $5 \mathrm{HT}$ depletor, was given. Food intake was significantly $(\mathrm{p}<0.01)$ increased by PCPA in day time and nighttime at the two temperatures. However, the food intake at $33^{\circ} \mathrm{C}$ was significantly $(p<0.01)$ less than that at $26^{\circ} \mathrm{C}$. The results of the present study suggest that the activation of serotoninergic neurons may not be the main factor controlling food intake inhibitively in a hot environment.
\end{abstract}

Anim. Sci. Technol. (Jpn.) 66 (7) : 594-598, 1995

Key words : cyproheptadine, $p$-chlorophenylalanine, serotonin, food intake, hot environment

Some neurotransmitters are believed to have an inhibitory influence over eating behavior. A monoamine, serotonin (5-hydroxytriptamine, $5 \mathrm{HT}$ ), is a convincing candidate for these neurotransmitters. Central and peripheral injections of $5 \mathrm{HT}$, its precursors, agonist and presynaptic releasers have consistently produced a suppression of fecding ${ }^{2}$.

Conversely, blockade of $5 \mathrm{HT}$ receptors and selective depletion of $5 \mathrm{HT}$ are correlated with overeating and increased body weight. BAXTER et al. ${ }^{1}$ reported that subcutaneous injection of the $5 \mathrm{HT}$ receptor blocker, cyproheptadine, 4- 5 H-dibenzo [a, d] cycloheptan-5- ylidene)-1-methylpiperdine, increased food consumption in fasted rats. BREISCH et al..$^{3}$ reported that rats given $p$-chlorophenylalanine (PCPA), a serotonin depletor, intraventricularly began overeating 3 days after the injection and continued to display marked hyperphagia.

Animals acclimated to a high ambient temperature have lower food intake than those acclimated to a moderate ambient temperature. HAMILTON $^{4)}$ showed that during chronic, mild $\left(32^{\circ} \mathrm{C}\right)$ and severe $\left(35^{\circ} \mathrm{C}\right)$ heat stress over a 21 days period, rats were observed to regulate food intake at a lower than normal levels. As for pig, feed consumption decreased as the air

* Present address : Faculty of Animal Science, Kitasato University, Towada-shi 034 


\section{Serotonin Effect on Food Intake in Hot Environment}

temperature increased from 40 to $100^{\circ} \mathrm{F}$, and it appeared that the decrease was more rapid at higher temperatures ${ }^{5)}$. WINCHESTER and MoRRIS $^{9)}$ reported that the decline in feed intake of cows appeared to begin only after the temperature reached $90^{\circ} \mathrm{F}$ while intake of lactating cows began to decline at about $70^{\circ} \mathrm{F}$. In our previous study, feeding elicited by noradrenaline was suppressed in the hot environment $t^{7)}$. In addition, it has been demonstrated that $5 \mathrm{HT}$ is particularly effective in suppressing feeding elicited by the injection of noradrenaline into the para-ventricular nucleus $(\mathrm{PVN})^{8)}$. The present series of experiment were conducted to examine the participation of $5 \mathrm{HT}$ in the regulation of appetite in rats acclimated to hot and temperate environments.

\section{Materials and Methods}

Male rats of Wistar strain weighing 350 to $400 \mathrm{~g}$ were used. They were kept under standard lighting conditions of $12 \mathrm{~h} /$ day arificial light, from $6: 00$ to $18: 00 \mathrm{~h}$. For intraventricular injection, a guide cannula of stainless steel was first fixed to the skull under sodium pentobarbital anesthesia. The cannula was $0.7 \mathrm{~mm}$ in outer diameter and $14 \mathrm{~mm}$ in length with a guard on the outside at $2 \mathrm{~mm}$ from the tip bottom. Employing a stereotaxic instrument the tip of the cannula was placed $6.5 \mathrm{~mm}$ anterior to the lambda and $1.3 \mathrm{~mm}$ left of the sagital suture. The injection cannula, stainless steel, with an outer diameter of $0.3 \mathrm{~mm}$, was inserted into the brain through the guide cannula to a distance of $4.5 \mathrm{~mm}$ under the guard; that is $17.4 \mathrm{~mm}$ from the top of the guide cannula. After a recovery period of 7 days, the animals were used for two kinds of experiments.

In the 1st experiment, the effect of a serotonin-receptor blocker, cyproheptadine, on short time eating was investigated in freely-fed rats at temperate $\left(26^{\circ} \mathrm{C}\right)$ and high $\left(33^{\circ} \mathrm{C}\right)$ ambient temperatures. The animals were divided into two groups, and acclimated to the two temperatures for 7 days. After the acclimation period, the experiment was started at 11:00 a. m. Cyproheptadine hydrochloride (Sigma, St. Louis, USA) dissolved in saline $(0.85 \%)$ was administered intraperitoneally at a dose of 15 $\mathrm{mg} / \mathrm{kg}$ body weight, and soon later $10 \mu \mathrm{g}$ of 1 noradrenaline bitartrate (Wako, Osaka, Japan) dissolved in $10 \mu l$ of saline was injected into the lateral ventricle. Soon after the injection, the rats ( $n=8$ per each group) were individually separated into one cage. They were given pre-weighed chow pellets (CE-2, Clea Japan. Inc.), and food intake during 2 hours was calculated as the difference between the original weight of pellets and those left in the cage plus the amount of crumbs found under the cage: The rats were allowed free access to chow pellets before the drugs were given.

In the 2nd experiment, the effect of PCPA on diurnal pattern of food intake was investigated at the two environmental temperatures. Every rats was stereotaxically implanted with a guide cannula of stainess steel directed into the left ventricle. The method of the operation was the same as the 1st experiment. After a recovery period of 7 days, the animals $(\mathrm{n}=11)$ were divided into two groups, and acclimated to temperate $\left(26^{\circ} \mathrm{C}\right)$ and hot $\left(33^{\circ} \mathrm{C}\right) \mathrm{am}-$ bient temperatures. Five days after the acclimation, each rat was given pre-weighed powdered chow (CE-2, Clea Japan lnc.) at 18 : $00 \mathrm{~h}$. Food intake in a nighttime was measured from $18: 00$ to $6: 00 \mathrm{~h}$, and that in a daytime was from $6: 00$ to $18: 00 \mathrm{~h}$. The food intake was measured daily. Seven days after the beginning of measurement of food intake, the rats were anesthetized with ether for easier injection, and received $3 \mathrm{mg}$ of PCPA in $20 \mu l$ of saline in to the ventricle at a rate of $10 \mu \mathrm{l} / \mathrm{min}$. The dose of PCPA was determined according to Breisch et al. ${ }^{3)}$. Over 7 days after the injection, the food intake was measured daily.

After the experiments, the animals were killed by ether and injected $10 \mu \mathrm{l}$ of $1 \%$ Evans 
blue solution. The brains were removed and sectioned for verifying adequacy of placement of the cannula. The dye was distributed not only in the lateral vertricle but also in the third ventricle in every case. Data were analyzed by two-way analysis of variance according to the $2 \times 2$ fractional scheme. And the statistical significance between two values was determined by $\mathrm{t}$-test.

\section{Results}

The central administration of noradrenaline exerted a stimulative effect on food intake at both temperatures (Table 1). However, the increment of food intake after noradrenaline administration at $26^{\circ} \mathrm{C}$ was greater than that at $33^{\circ} \mathrm{C}(1.0$ vs. $0.4 \mathrm{~g})$. An additive increment of food intake was not observed after cyproheptadine administration in rats given noradrenaline simultaneously. Food intake was in creased by cyproheptadine only when the drug was administered at $26^{\circ} \mathrm{C}$. Food intake was gradually increased after PCPA administra- tion, and reached the peak three to four days after the administration. The means of food intake for five days, from five days to one day before and from three days to seven days after PCPA administration, were shown in Table 2. In a day time, there was not a significant in food intake between 26 and $33^{\circ} \mathrm{C}$ before PCPA was given. In a nighttime, however, food intake at $26^{\circ} \mathrm{C}$ was significantly $(\mathrm{p}<0.01)$ greater than that at $33^{\circ} \mathrm{C}$. Food intake was significantly ( $p$ $<0.01)$ increased after PCPA administration at the both temperatures. In addition, food intake at $26^{\circ} \mathrm{C}$ was significantly $(\mathrm{p}<0.01)$ greater than that at $33^{\circ} \mathrm{C}$ in daytime and nighttime.

\section{Discussion}

In the present study, noradrenaline increased food intake in rats in hot and temperate environments. However, the increment of food intake by noradrenaline in the hot environment was less than that in the temperate environment. Serotonin $(5 \mathrm{HT})$ is one of neurotransmitters causing satiety ${ }^{2)}$. We expected

Table 1. The effects of intraventricular injection of noradrenaline (NA, $10 \mu \mathrm{g}$ ) and intraperitoneal administration of cyproheptadine (CYP, $15 \mathrm{mg} / \mathrm{kg} \mathrm{BW}$ ) on food intake in rats kept at temperate $\left(26^{\circ} \mathrm{C}\right)$ and hot $\left(33^{\circ} \mathrm{C}\right)$ ambient temperatures ${ }^{1)}$

\begin{tabular}{|c|c|c|c|c|c|c|c|}
\hline & \multicolumn{2}{|c|}{$\mathrm{SAL}$} & \multicolumn{2}{|c|}{ NA } & \multicolumn{3}{|c|}{ Analysis of variance ${ }^{2)}$} \\
\hline & SAL & CYP & SAL & CYP & $\mathrm{NA}$ & CYP & $\mathrm{NA} \times \mathrm{CYP}$ \\
\hline $26^{\circ} \mathrm{C}$ & $0.9 \pm 0.2^{\mathrm{a}}$ & $1.6 \pm 0.1^{\mathrm{b}}$ & $1.9 \pm 0.2$ & $1.5 \pm 0.1$ & $* *$ & NS & $* *$ \\
\hline $33^{\circ} \mathrm{C}$ & $0.1 \pm 0.1$ & $0.3 \pm 0.1$ & $0.5 \pm 0.1$ & $0.7 \pm 0.1$ & $* *$ & NS & NS \\
\hline
\end{tabular}

i) Values represent means for eight rats with $\mathrm{SE}$.

2)**: $\mathrm{p}<0.01$, NS : not significant.

a, : Significant difference between saline (SAL)- and CYP-treatment in each treatment $(p<0.01)$.

Table 2. The effects of intraventricular injection of p-chlorophenylalanine (PCPA, $3 \mathrm{mg}$ ) and ambient temperatures on food intake of rats in daytime and nighttime ${ }^{1)}$

\begin{tabular}{|c|c|c|c|c|c|c|c|}
\hline & \multicolumn{2}{|c|}{ pre-PCPA } & \multicolumn{2}{|c|}{ post-PCPA } & \multicolumn{3}{|c|}{ Analysis of variance } \\
\hline & $26^{\circ} \mathrm{C}$ & $33^{\circ} \mathrm{C}$ & $26^{\circ} \mathrm{C}$ & $33^{\circ} \mathrm{C}$ & Temp. & PCPA & Temp. $\times$ PCPA \\
\hline Day time & $4.8 \pm 0.3$ & $3.9 \pm 0.3$ & $9.6 \pm 0.7^{a}$ & $6.8 \pm 0.4^{b}$ & *** & $* *$ & * \\
\hline Nighttime & $12.4 \pm 0.1^{\mathrm{a}}$ & $8.2 \pm 0.2^{b}$ & $17.1 \pm 0.3^{a}$ & $13.1 \pm 0.7^{b}$ & ** & $* *$ & NS \\
\hline
\end{tabular}

1) Values represent means of food intake for five days with $S E$. The numbers of rats used were seven and four at 26 and $33^{\circ} \mathrm{C}$, respectively.

${ }^{2)} *: p<0.05,{ }^{* *}: p<0.01, \mathrm{NS}:$ not significant.

a,b : Significant difference between 26 and $33^{\circ} \mathrm{C}$ in each treatment $(p<0,01)$. 
that serotoninergic activity might suppress feeding in the hot environment. Cyproheptadine blocks $5 \mathrm{HT}$ receptors, thus suppressing the activity of $5 \mathrm{HT}$ neurons. Nevertheless, food intake was not additionally increased by cyproheptadine in rats given noradrenaline in the hot enviroment. Consequently, serotoninergic activity might not be correlated with the suppression in eating elicited by noradrenaline in the hot enviroment. On the other hand, cyproheptadine alone increased food intake only in the temperate environment. LEIBOwITZ et al ${ }^{8)}$ have suggested that $5 \mathrm{HT}$ may suppress feeding by directly acting to increase the firing of PVN satiety neurons, and that $\alpha 2$-adrenergic receptors on $5 \mathrm{HT}$ presynaptic terminals reduce $5 \mathrm{HT}$ release and consequently disinhibit . eating. The failure to increase food intake by the $5 \mathrm{HT}$ antagonist suggests that there may be satiety neurons besides serotoninergic neurons, directly activating satiety neurons within or without the PVN in the hot environment. The reduced increment of food intake after noradrenaline in the hot environment may be due to the same mechanism in the case of cyproheptadine alone, because both noradrenaline and cyproheptadine suppress serotoninergic neurons.

Rats are a nocturnal animal, and eat more food in nighttime than in daytime. Interestingly, there was not significant difference in food intake in the daytime between hot and temperate environments before PCPA was given. Following PCPA administration, however, feeding was activated in both daytime and nighttime, and food intake at the low temperatute was greater than that at the high temperature. The activation of feeding neurons may be suppressed by satiety neurons in the hot environment. PCPA is a drug which disturbs $5 \mathrm{HT}$ synthesis and then depletes $5 \mathrm{HT}$. BREISCH et $a l .^{3)}$ showed that hyperphagia was related to drug dose and to the degree and duration of $5 \mathrm{HT}$ depletion. If hyperphagia after PCPA is caused by inactivation of serotoninergic neurons, the reduced increment of food intake in the hot environment suggests that satiety neurons besides serotoninergic neurons may be activated in the hot environment. Holmes et al. ${ }^{6)}$ have concluded that elevated activity of noradrenergic neurons, rather than decreased serotoninergic activity, in the medial basal hypothalamus may cause hyperphagia following PCPA administration. If noradrenaline stimulates feeding through inhibiting $5 \mathrm{HT}$ release as suggested by LEIBOwITZ et $a l .^{8)}$, the decrease in food intake in the hot environment can be explained by activation of satiety neurons besides serotoninergic neurons. The results of the present study suggest that the activation of serotoninergic neurons may not be the main factor controlling food intake inhibitively in a hot environment.

\section{References}

1) BAxter, M.G., A.A. Miller and F.E. Soroko, The effect of cyproheptadine on food consumption in the fasted rat. Brit. J. Pharmacol., 39 : 229-230. 1970.

2) Blundell, J.E., Serotonnin and appetite. Neuopharmacolgy, 23 : 1537-1552. 1984.

3) BReISCH, S.T., F.P. ZEMLAN and B.G. HOEBel, Hyperphagia and obesity following serotonin depletion by intraventricular $p$ - chlorophenylalanine. Science, $192: 382-385.1976$.

4) HAMiLTON, C.L., Interactions of food intake and temperature regulation in the rat. J. Comp. Physiol. Psychol., 56 : 476-488. 1963.

5) Heitman, H. and E.H. HughEs, The effects of air temperature and relative humidity on the physiological well being of swine. J. Animal Sci., 8 : 171-181. 1949.

6) Holmes, L.J., L.H. Storlen and G.A. SMythe, Medial basal hypothalamic monoamine activity associated with intracerebroventricular $p$ chlorophenylalanine-induced hyperphagia. Brain Res., $528: 269-272.1990$.

7) KuRose, Y., H. YANO and A. MrYAZAKI, Effect of $\beta$-adrenoceptor antagonist, propranolol, on feeding induced by noradrenaline and muscimol in rats kept at high and temperateambient temperatures. Eur. J. Pharmacol, 211 : 39-42. 1992.

8) Leibowitz, S.F. and B.G. Stanley, Neurochem- 
ical controls of appetite. In : Feeding behavior (RitTER, R.C., S. RitTER and C.D. BarNes, eds.). 191-234. Academic Press. Orlando. 1986.
9) WINCHESTER, C.F. and MORRIS, M.J., Water intake rates of cattle. J. Animal Sci., $15: 722-$ 740. 1956.

\title{
暑熱ならびに快適環境に馴化したラットの摂食に対するセロトニン 阻害薬シプロヘプタジンおよびセロトニン合成阻害薬 $p$-クロロフェニルアラニンの影響
}

\author{
黑瀬陽平 $*$ 矢野秀雄 $\cdot$ 宮崎 昭 \\ 京都大学農学部，京都市左京区 606
}

\begin{abstract}
本研究の目的は，暑熱環境における食欲減退にセロトニンが関与する可能性をラット（雄，体重 350〜 $400 \mathrm{~g})$ を用いて検討した，実験 1 では，試薬投与前 7 日間，暑熱 $\left(33^{\circ} \mathrm{C}\right)$ および快適㻴境 $\left(26^{\circ} \mathrm{C}\right)$ 下で ラット走飼育した，試薬投与直前まで自由採食とした，ノルアドレナリン $(10 \mu \mathrm{g})$ を則脳空投与すると

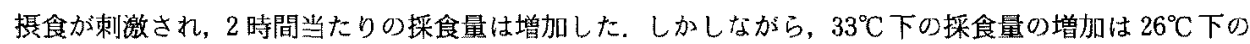
採食量の增加よりも少な加った ( $0.4 \mathrm{vs} .1 .0 \mathrm{~g})$ ）七ロトニン拮抗薬シプロヘプタジン ( $15 \mathrm{mg} / \mathrm{kg}$ 体重) をノルアドレナリンと同時投与しても，採食量がノルアドレナリン単独投与の場合より多くなることは なかった，したがってセロトニン神経の活性化は，ノルアドレナリンによる摄食が暑熱環境下において 抑制される要因ではない，シプロヘプタジン単独投与後 2 時間の採食量を測定すると， $26^{\circ} \mathrm{C}$ 下では採食 量が增加したが， $33^{\circ} \mathrm{C}$ 下では增加しなかった，実験 2 において，7日間の温度馿化後，1日当たりの採食 量を明期および暗期に分けて 5 日間測定したところ，明期の採食量は両環境間で差がなかった。七ロト ニン合成阻害楽 $p$-クロロフェニルアラニン (PCPA, $3 \mathrm{mg}$ ) を側脳空投与すると，両環境下で，明期お よび暗期の採食量が增加した．PCPA 投与 3 日後から 7 日後までの 5 日間の採食量は，朋期および暗期 とあに $33^{\circ} \mathrm{C}$ 下の方が $26^{\circ} \mathrm{C}$ 下上りあ少なかった．以上の結果は，七ロトニン神経の活性化が暑熱環境下 に抢ける食欲の減退に関与しないことを示唆している.
\end{abstract}

日畜会報, $66(7): 594-598,1995$

* 現所属 : 北里大学獸医畜産学部, 十和田市 034 